\title{
ANTIAPOPTOTIC PROTEINS MCL-1 AND BCL-2 AS WELL AS GROWTH FACTORS FGF AND VEGF INFLUENCE SURVIVAL OF PERIPHERAL BLOOD AND BONE MARROW CHRONIC LYMPHOCYTIC LEUKEMIA CELLS
}

Predrag Djurdjevic ${ }^{1,2}$, Danijela Jovanovic ${ }^{1,2}$, Dejan Baskic ${ }^{3}$, Suzana Popovic ${ }^{3}$,

${ }^{1}$ University of Kragujevac, Serbia, Faculty of Medical Sciences, Department of Internal medicine ${ }^{2}$ Clinical centre Kragujevac, Serbia, Clinic for Hematology

${ }^{3}$ University of Kragujevac, Serbia, Faculty of Medical Sciences, Department of Microbiology and immunology

\author{
ANTIAP OPTOTSKI PROTEINI MCL-1 I BCL-2 IKAO I VASIKULARNI \\ ENDOTELNI FAKTOR RASTA (VEGF) I FIBROBLASTNI FAKTOR RASTA \\ (FGF) UTIČU NA PREŽIVLJAVANJE ĆELIJA HRONIČNE LIMFOCITNE \\ LEUKEMIJE U PERIFERNOJ KRVI I KOSTNOJ SRŽI

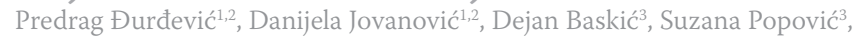 \\ ${ }^{1}$ Univerzitet u Kragujevcu, Fakultet medicinskih nauka, Katedra za Internu medicinu \\ ${ }^{2}$ Klinički centar Kragujevac, Srbija, Klinika za hematologiju \\ ${ }^{3}$ Univerzitet u Kragujevcu, Fakultet medicinskih nauka, Katedra za mikrobiologiju i imunologiju
}

Received / Primljen: 12. 06. 2018.

Accepted / Prihvaćen: 18. 07. 2018.

\begin{abstract}
Apoptosis inhibition in chronic lymphocytic leukemia (CLL) is one of the most important mechanism in the disease onset, progression and therapy response and is dependent of interaction with different microenvironments.
\end{abstract}

Aim of our paper is to determine expression of antiapoptoic proteins $\mathrm{mcl}-1$ and $\mathrm{bcl}-2$ in CLL cells isolated from two different compartments (peripheral blood and bone marrow) and its relation to percent of apoptotic cells and concentration of growth factors (FGF and VEGF).

Our results showed that peripheral blood CLL lymphocytes have lower apoptotic rate then those isolated from bone marrow, though bone marrow CLL lymphocytes express higher levels of antipoptotic proteins bcl-2 and mcl-1. In bone marrow FGF concentration is 10-fold higher then in patients plasma but has an limited impact on mcl-1 expression. In contrary, VEGF concentration is higher in peripheral blood and corelate with percent of apoptotic cells and mcl-1 expression in this compartment.

CLL cells derived from two different microenvironmets acts differently when tested for apoptosis „ex vivo". In peripheral blood apoptosis is strongly connected with expression of antiapoptoic proteins ( $m c l-1$ and bcl-2) and growth factors, but not in bone marrow.

Keywords: CLL, apoptosis, mcl-1, VEGF, FGF

\section{SAŽETAK}

Inhibicija apoptoze u hroničnoj limfocitnoj leukemiji (HLL) predstavlja jedan od najvažnijih mehanizama kako nastanka bolesti, tako i progresije ali $i$ odgovora na primenjivanu terapiju $i$ zavisi od interakcije malignog limfocita sa različitim mikrosredinama.

Cilj našeg rada je odrediti ekspresiju antiapoptotskih proteina mcl-1 i bcl-2 u HLL limfocitima izlovanim iz dve različite mikrosredine (periferne krvi $i$ kostne srži) $i$ njihovu povezanost sa procentom apopotičnih limfocita kao $i$ koncentracijom faktora rasta (VEGF i FGF).

Naši rezultati su pokazali da HLL limfociti izolovani iz periferne krvi imaju manji procenat apoptoze nego oni izolovani iz kostne srži, iako im je ekspresija antiapopotskih proteina bcl-2 i mcl-1 niža. U mikrosredini kostne srži koncentracija FGF je 10 puta veća nego u plazmi pacijenata, ali je njen uticaj na ekspresiju mcl-1 minimalan. Sa druge strane koncentracija VEGF je veća u perifernoj krvi i korelira sa procentom apoptotskih limfocita kao i ekspresijom mcl-1 u HLL limfocitima izolovanim iz periferne krvi.

Limfociti hronične limfocitne leukemije izlovani iz dve različite mikrosredine pokazuju značajnu razliku u procentu „ex vivo" testirane apoptoze. U perifernoj krvi procenat apoptotskih ćelija snažno je povezan sa ekspresijom antiapopototskih proteina ( $m c l-1$ i bcl-2) kao i koncentracijom faktora rasta, dok u kostnoj srži ove povezanosti nema.

Ključne reči: $H L L$, apoptoza, mcl-1, VEGF, FGF

\section{ABBREVIATIONS}

Bcl-2 - B cell lymphoma 2 protein mcl-1- myeloid leukemia cell 1 protein
VEGF - vascular endothel growth factor

FGF - fibroblast growth factor

CLL - chronic lymphocytic leukemia

\section{sciendo}

UDK: 612.014.3:576.36

616.155.392

Ser J Exp Clin Res 2020; 21 (2): 133-139

DOI: 10.2478/SJECR-2018-0025

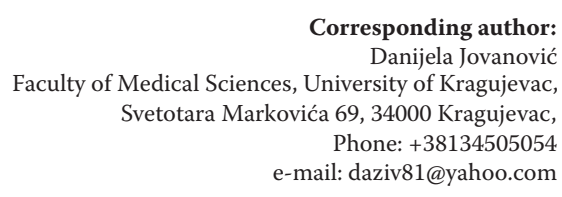




\section{INTRODUCTION}

Apoptosis inhibition in chronic lymphocytic leukemia (CLL) cells stands as one of the most important mechanisms in the disease onset, but as well as in progression and therapy response. Multiple mechanisms of CLL cells apoptosis resistance have been discovered and described so far, but most important is definitely intrinsic pathway represented through bcl-2 family members (bcl-2, mcl-1, bcl-XL, Bax, Bad) (1). These antiapoptotic pathways are potent and keeps the cells long living. The bcl-2 protein is important for maintenance of $\mathrm{B}$ lymphocyte population in adults (long living memory cells) in normal hematopoesis while mcl-1 predominantely follows hematopoetic stem cell and B cell differentiation process $(2-4)$. In CLL cells concentrations of these proteins are elevated due to enhanced syntesis, but also their reduced clevage. It is mostly due to hypomethylation of the promoter bcl-2 region as well as lack of microRNA 15,16 and 29, which leads to accumulation of bcl-2 and mcl-1 in the CLL cells, resulting in the prolonged survival $(1,5)$. Yet, when cultivated in vitro in monocultures, CLL cells undergo apoptosis in the higher percent than healthy B lymphocytes, which imposes a conclusion that prolonged survival is not characteristic od CLL cell itself, but is a product of interaction of CLL cell with protective microenvironment(6). The bone marrow and lymph node are two most important microenvirontems for proliferation, apoptosis inhibition and drug resistance of CLL cells. Predominantly stromal „nurse like" cells, but also endothelial cells in these microenvironments, through cell-cell interaction and soluble molecules modulate CLL cells in their apoptotic and proliferation signals. Pathogenesis of CLL is also impacted by angiogenesis in these protective microenvironments. Vascular endothelial growth factor (VEGF) is pro-angiogenic factor with multiple roles proved in CLL. Its stimultion of angiogenesis is associated with an advanced stage of the disease, resistance to apoptosis and cell motility. $(7,8,9)$. Fibroblast growth factor (FGF) in tumors promotes angiogenesis, has important role in proliferation of stromal cells and thus modify microenviroment $(10,11)$.

Aim of our paper is to determine expression of antiapoptoic proteins mcl-1 and bcl-2 in CLL cells isolated from two different compartments (peripheral blood and bone marrow) and its relation to percent of apoptotic cells and concentration of growth factors (FGF and VEGF) in these microenvironments.

\section{PATIENTS AND METHODS}

\section{Study population and sample collection}

In our study we evaluated 60 samples (30 peripheral blood and 30 matching bone marrow samples) from 30 patients diagnosed with chronic lymphocytic leukemia. Patients were at least 6 months without any chemotherapy and not suffering from other acute and chronic condition which could impact tested parameters. The study was approved by the Ethical Committee of the Clinical Center Kragujevac. All patients gave their written informed consent according to the Declaration of Helsinki. Democraphic data of our patients group refers to typical CLL patients, average age 67 years $(53-87)$ with male predomination (22 males and 8 women). For study purpose we collected $5 \mathrm{ml}$ of peripheral blood and $4 \mathrm{ml}$ of bone marrow aspirate from each patient. Native samples were used for determination of expression of mcl-1 and bcl-2 in the CLL cells, while from the rest we isolated mononuclear cells and plasma and bone marrow supernatant. Plasma and bone marrow supernatant were quickly frozen to $-70 \mathrm{C}$ and collected for determination of VEGF and FGF concentration. The mononuclear cells were isolated using comerrcial gradient LymphoPrep and used for the apoptosis detection.

\section{Detection of antiapoptotic proteins}

Peripheral blood and bone marrow aspirate samples of patients were analyzed using 5-color flow cytometry. Analyzing sample was prepared using $50 \mu \mathrm{l}$ of whole blood, incubated $15 \mathrm{~min}$ on room temperature with surface markers, and then dyed for intracellular markers (mcl-1 and bcl2) using commercial intarcellular kit IntraPrep (Beckman Coulter 2389). Antibody sources were as follows: CD19 fitc Beckman Coulter (Cat.No A07768), CD5 PE-Cy7 Beckman Coulter (Cat.No A21690), bcl-2 pe (Invitrogen MHBCLO4 ), mcl-1 8C6D4B1 (Abcam ab31948) and Goat anti mouse IgG pe (Abcam ab97041). Cells were analysed in the CD19/ CD5 gate and expression was determined as postive/negative and low/high according to the isotypic control and MFI values. Samples were analysed on BC FC 500.

\section{Growth factors mesaurments}

Concentration of VEGF and FGF in plasma and bone marrow supernatant were determined using a commercial flowcytometric kit Human VEGF-A Flowcitomix Simplex Kit (e-bioscience, BMS80277FF), Human FGF-2 Flowcitomix Simplex Kit (e-bioscience, BMS82074FF) on a FC500 Beckman Coulter Flow Cytometer according to the manufacturer's instructions. Collected data were analyzed using FlowCytomix ${ }^{\mathrm{mm}}$ Pro 3.0 Software.

\section{Detection of apoptotic lymphocytes}

Apoptotic cells were detected on flow cytometer on isolated mononulclear cells, dyed using commercial kit Annexin V-FITC/7-AAD kit (BC IM3614) according to the manufacturer's instructions. Finally, cells were analyzed on an FC500 Beckman Coulter flow cytometer to the number of 20000 events, gating lymphocytes and CD19+ cells. In the analysis Annexin $\mathrm{V}$ negative and 7-AAD negative cells are viable, Annexin $\mathrm{V}$ positive and 7-AAD negative cells are in the early stages of apoptosis, Annexin $V$ positive and 7-AAD 
Table 1. Median values of tested parametrs in peripheral blood and bone marrow

\begin{tabular}{|l|l|l|l|}
\hline & Peripheral blood & Bone marrow & p value \\
\hline \% of CD19+ cells in early apoptosis & $0,03(0,0001-0,22)$ & $0,155(0,025-0,38)$ & $\mathbf{0 , 0 6 8}$ \\
\hline \% of CD19+ cells in late apoptosis & $0,001(0,0001-0,18)$ & $0,13(0,03-0,58)$ & $\mathbf{0 , 0 0 5}$ \\
\hline \% of cells with high bcl-2 expression & $12,29(0,71-52,74)$ & $1,36(0,15-66,36)$ & 0,323 \\
\hline \% of cells with mcl-1 expression & $52,06(20,9-65,8)$ & $37,22(15,7-58,39)$ & 0,13 \\
\hline VEGF $(\mathrm{pg} / \mathrm{ml})$ & $24,44(21,16-58,05)$ & $21,69(17,14-25,10)$ & 0,791 \\
\hline FGF $(\mathrm{pg} / \mathrm{ml})$ & $103,75(86,67-119,51)$ & $1106,24(299,64-2360,87)$ & $<\mathbf{0 , 0 0 5}$ \\
\hline
\end{tabular}

positive cells are in late stages of apoptosis, while Annexin V negative and 7-AAD positive cells are necrotic. The percentages of early and late apoptotic cells, as well as necrotic cells were determined using CXP Cytometer software.

\section{RESULTS}

We determined percent of apoptotic CD19+ cells in peripheral blood $(\mathrm{PB})$ and bone marrow $(\mathrm{BM})$, as well as expression of bcl-2 and mcl-1 in CD19+/CD5+ CLL cells and concentration of VEGF and FGF in both patients plasma and bone marrow supernatnt. These results comparing values from both compartments were presented in the table 1.

Peripheral blood lymphocytes show lower percentage of cells in both early and late apoptosis when tested „ex vivo" compared to the lymphocytes isolated from bone marrow, though the cells does not have significant difference in expression of antiapoptotic proteins (bcl-2 and mcl-1). (Figures 1 and 2). Concentration of VEGF in PB and $\mathrm{BM}$ does not differ significantly, while concentration of FGF in BM is 10-fold higher then in PB.
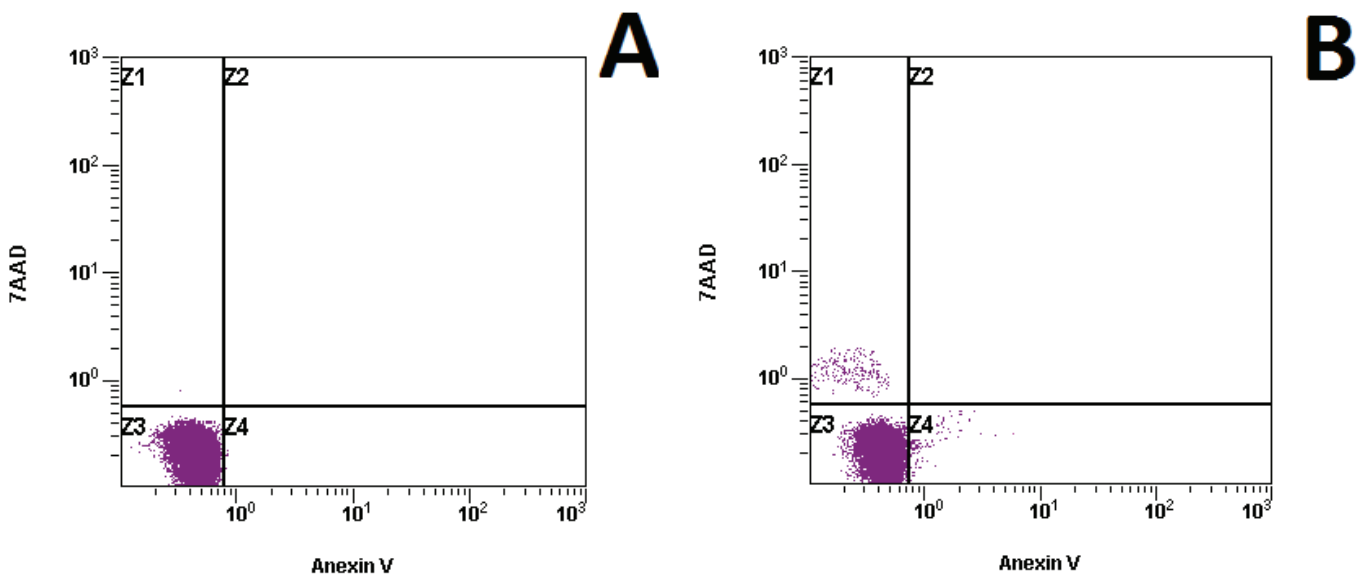

Figure 1. Dot plots showing apoptotic rate of lymphocys derived from peripheral blood (A) and bone marrow (B)
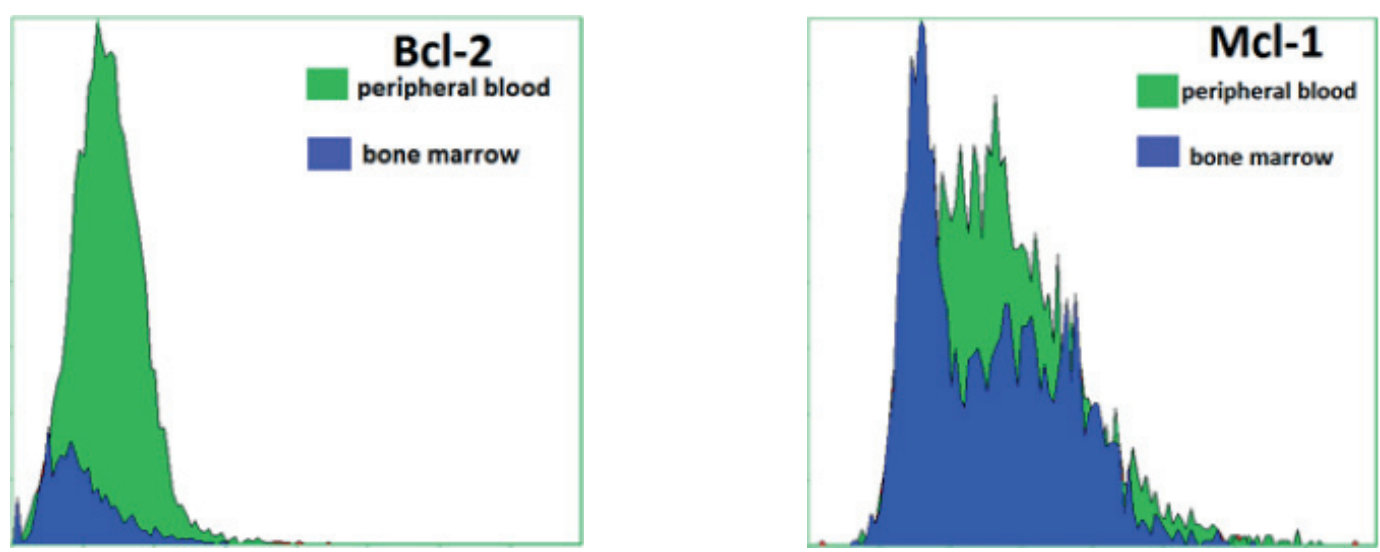

Figure 2. Overlay histograms showing expression of bcl-2 (left) and mcl-1 (right) in the CLL lymphocytes derived from peripheral blood and bone marrow 
Expression of mcl-1 in bone marrow derived CLL cells correlate positivly with percent of both early and late apoptotic cells in bone marrow $r^{2}=0,453 p=0,016$, while it does not correlate with percent of apoptotic cells in peripheral blood $\mathrm{r}^{2}=0,191 \mathrm{p}=0,313$.

Early and late apoptosis in bone marrow are in strong positive correlation with concentration of VEGF $\mathrm{r}^{2}=0,704$ $\mathrm{p}<0,0001$ and $\mathrm{r}^{2}=0,554 \mathrm{p}=0,002$ respectivly. Also there is a strong positive correlation between FGF concentration in bone marrow with CLL cells early apoptosis in bone marrow $\mathrm{r}^{2}=0,611 \mathrm{p}=0,001$, as well as with CLL cells late apoptosis in bone marrow $\mathrm{r}^{2}=0,620 \mathrm{p}<0,0001$
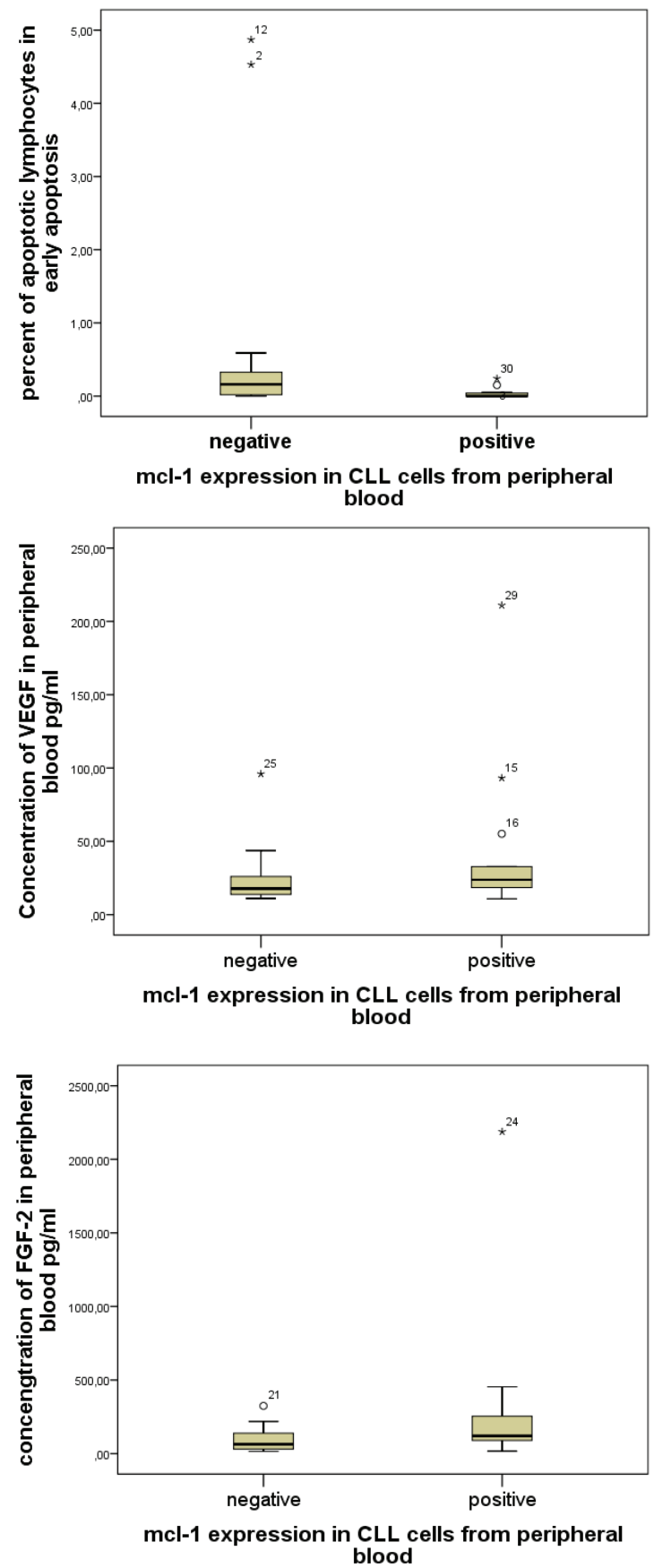

Figure 3. Apoptosis of CLL cells, VEGF and FGF concentration in peripheral blood depending on positivity of CLL cells to mcl-1
Results showed that when CLL cells in peripheral blood exprime mcl-1 molecule we have higher concentration of VEGF in peripheral blood $(24,8 \pm 21,14$ versus $42,98 \pm 52,73$ $\mathrm{pg} / \mathrm{ml}, \mathrm{p}=0,077$ ), higher concentration of FGF in peripheral blood $(98,66 \pm 88,1$ versus $309,4 \pm 552,84 \mathrm{pg} / \mathrm{ml}, \mathrm{p}=$ $0,031)$, and lower early apoptotic rate $(0,73 \pm 1,56 \%$ versus $0,038 \pm 0,07 \%, p=0,006$ ) (Figure 3 ). There is no statisticaly significant difference in late apoptotic rate or bcl-2 expression in these cells.

There is no statisticaly significant difference in bcl-2 molecule expression, rate of early and late apoptosis, or concentration of VEGF and FGF in bone marrow supernatant between the mcl-1 positive and negative CLL cells.

Though there has been detected significant medium to strong correlation between mcl-1 expression in peripheral blood and bone marrow samples, $\mathrm{r}^{2}=0,524 \mathrm{p}=0,004$.

\section{DISCUSSION}

Microenviroment studies in CLL has been in progress in the last decades thanks to which our view to CLL patients and its treatment has been changed. Protective role of microenvironments are the reasons for this disease to have so many faces.

CLL cells undoubtly have lower apoptotic rate comparred to lymphocytes isolated from peripheral blood of healthy subjects (12). But unlike most other studies that promote better survival of CLL cells in the protective microenvironments (bone marrow and lymph nodes), our results show that bone marrow derived CLL lymphocytes have higher apoptotic rate then those isolated from peripheral blood. Those results indirectly points that protective microenvironment acts in site, but does not make a permanent change in CLL cell which make it more prone to apoptosis when taken away from microenviromnent signals. So Siekluska at al, and Witkowska et al showed that there is a greater apoptotic rate when CLL cells are tested "ex vivo", just as our work showed, and that it can be correlated with the disease progression $(13,14)$.

Main mechanism of CLL cell survival is apoptosis inhibition. All known apoptotic pathways were investigated in CLL, with conclusion that most impact deffinitely belongs to bcl-2 family proteins (15). This mechanism is widely used in the field of introducing novel therapies (15). Mcl-1 protein together with Act and in lot less percent other members of bcl-2 family (bcl-2 and bcl-XL) are the main regulators of apoptosis resistance in CLL cells. (16) Mcl-1 can be upregulated by several mechanisms, most of which include B cell receptor activation, which suggest that extrinsic as well as intrinsic factors cooperate in disease onset, progression and therapy resistance (16). All these mechanisms depends on stromal-mediated increase in RNA synthesis which could be a result of activation of transcription factors such as c-myc and NFkB (17). Since mcl- 1 is an early responder and a fast turnover molecule it is amplified more then other proteins. Being a short living 
molecule, there is a constant equlibrium between stabilisation and degradation of mcl-1, but in CLL cell it outweigh in favor of mcl-1 accumulation (17). Our results show that peripheral blood CLL lymphocytes have higher expression of mcl- 1 then those derived from bone marrow, which suggest that mcl-1 expression is more important in antiapoptoic effect in peripheral blood.

Answer to the question of origin of VEGF in CLL is not simple. While Kay et al, and Chen et al came to the conclusion that CLL cells themselves secrete VEGF, Gehrke et al proved that only stromal cell derived VEGF have protective effect on CLL cells $(18$ - 20). Our results showing that plasma concentration of VEGF is higher that in bone marrow supernatant, give advantage to the fact that CLL cells themselves produce VEGF. Our results also showed that ex vivo apoptosis is accelerated in bone marrow comparing to peripheral blood CLL cells. CLL cells have receptors for VEGF on the cell membrane, expriming both VEGFR1 and VEGF R2 (13). When binded to these receptors VEGF increase apoptotic resistance of cells interact with STAT1 and STAT3 which ends up in upregulation of XIAP and mcl-1 expression $(8,21,22)$. Also VEGFR expression in CLL cells are stimulated by endothelin -1 receptor signaling through hypoxia inducible factor 1, suggesting the impact of endotel cells in CLL survival $(23,24)$. Our results show greater concentration of VEGF in peripheral blood then in bone marrow, as well as a strong connection between mcl-1 expression and concentration of VEGF in peripheral blood, which also suggest that VEGF is secreted in peripheral blood and not overflow from bone marrow. Also VEGF mRNA levels in CLL cells are in strong positive correlation with mcl-1 expression (25).

Basic FGF (FGF-2) has an important role in early hematopoesis in proliferation of hemangioblasts, common progenitor cells for hematopoetic and endotel cells (26). For those reasons FGF is mostly investigated for its effect on endothelial cells. Concerning survival of endothelial cells in culture, adding FGF promote longer survival in the early phase because of the better cell adherence, and latter due to activation of MAP kinase, FGF promotes upregulation of antiapoptotic proteins (27). Out of bcl2 protein family, FGF is proven to upregulate only bcl2 protein (27). In our work we have proved that there is a relatively high concetration of FGF in patients plasma, but not significantly different from those in healthy subjects, but even 10-folder higer in bone marrow supernatant. (12) Several investigator proved that FGF is mostly secreted by stromal and endotel cells, and that its major role is in proliferation of bone marrow stromal cells (28). Also its concentration in CLL patients is higher than in the healthy control subjects $(26,29,30)$. Similary to its effect in endothelial cells it is proven that FGF have a protective role in CLL cell survival, and that it has an impact on bcl-2 upregulation, but no effect on levels of mcl-1. (30). Beside longer survival, higher levels of FGF and presence of upregulated FGF-2 receptors on CLL cells are connected with resistance to standard fludarabine therapy (28). Our results show that levels of FGF in bone marrow strongly correlates with percent of apoptotic CLL cells, as well as with level of mcl-1, and not level of bcl-2 which is not in concordance with other results. Our results indirectly point to conection between FGF level in bone marrow and mcl-1 expression, which could be possible mechanism of FGF effect on CLL cell. Though the FGF effect should be further investigated towards its connection to mcl-1 molecule.

\section{CONCLUSION}

CLL cells derived from two different microenvironmets show different rate of apoptosis „ex vivo“. In peripheral blood CLL cells apoptosis is strongly connected with expression of antiapoptoic proteins (mcl-1 and bcl-2) and growth factors, but not in bone marrow. However, these mechanisms are just a part of complex regulatory system.

\section{ACKNOWLEDGEMENTS}

This study was supported by grant JP 11/12 from Faculty of medical sciences, University of Kragujevac, Republic of Serbia.

There is no conflict of interest concerned in this paper.

\section{REFERENCES}

1. Buggins AG \& Pepper CJ. (2010) The role of Bcl-2 family proteins in chronic lymphocytic leukaemia. Leuk Res. 34(7):837-42 DOI:10.1016/j.leukres.2010.03.011

2. Veis DJ, Sorenson CM, Shutter JR \& Korsmeyer SJ.(1993) Bcl-2-deficient mice demonstrate fulminant lymphoid apoptosis, polycystic kidneys, and hypopigmented hair. Cell. 75:229-240. DOI: 10.1016/00928674(93)80065-M

3. Opferman JT, Iwasaki H, Ong CC, Suh H, Mizuno S, Akashi K \& Korsmeyer SJ. (2005) Obligate role of anti-apoptotic MCL-1 in the survival of hematopoietic stem cells. Science. 307:1101-1104. DOI: 10.1126/science.1106114

4. Opferman JT, Letai A, Beard C, Sorcinelli MD, Ong CC \& Korsmeyer SJ. (2003) Development and maintenance of $\mathrm{B}$ and T lymphocytes requires antiapoptotic MCL-1. Nature. 426:671- 676. DOI: 10.1038/nature02067

5. Cimmino, A., Calin, G.A., Fabbri, M. et al. (2005) miR15 and miR-16 induce apoptosis by targeting BCL2. Proc Natl Acad Sci USA. 102: 13944-13949. DOI: 10.1073/pnas.0506654102

6. Burger JA, Ghia P, Rosenwald A \& Caligaris-Cappio F.(2009) The microenvironment in mature B-cell malignancies: a target for new treatment strategies. Blood. 114:3367-75. DOI: 10.1182/blood-2009-06-225326 
7. Maffei R, Martinelli S, Castelli I, Santachiara R, Zucchini P, et al (2010) Increased angiogenesis induced by chronic lymphocytic leukemia B cells is mediated by leukemia-derived Ang2 and VEGF. Leuk Res 34: 312321. DOI: $10.1016 /$ j.leukres.2009.06.023

8. Farahani M, Treweeke AT, Toh CH, Till KJ, Harris RJ, et al (2005) Autocrine VEGF mediates the antiapoptotic effect of CD154 on CLL cells. Leukemia. 19:524-530. DOI: 10.1038/sj.leu.2403631

9. Gehrke I, Gandhirajan RK, Poll-Wolbeck SJ, Hallek M \& Kreuzer KA (2011) Bone marrow stromal cell-derived vascular endothelial growth factor (VEGF) rather than chronic lymphocytic leukemia (CLL) cell-derived VEGF is essential for the apoptotic resistance of cultured CLL cells. Mol Med 17: 619-627. DOI: 10.2119/ molmed.2010.00210

10. Akl MR, Nagpal P, Ayoub NM, Tai B, Prabhu SA, Capac CM, Gliksman M, Goy A \& Suh KS. (2016) Molecular and clinical significance of fibroblast growth factor 2 (FGF2 /bFGF) in malignancies of solid and hematological cancers for personalized therapies. Oncotarget. 12;7(28):44735-44762. DOI: $10.18632 /$ oncotarget.8203.

11. Ribatti D, Vacca A, Rusnati M \& Presta M. (2007) The discovery of basic fibroblast growth factor/fibroblast growth factor- 2 and its role in haematological malignancies. Cytokine \& Growth Factor Reviews 18: 327334. DOI: DOI: 10.1016/j.cytogfr.2007.04.011

12. Jovanović DD (2015). Prognostic markers and apoptosis of malignant lymphocytes derived from peripheral blood and bone marrow. Unpublished doctoral dissertation, University in Kragujevacv, Kragujevac, Serbia (in Serbian)

13. Sieklucka M, Bojarska-Junak A, Surdacka A, Hus I, Wasik-Szczepanek E, Dmoszynska A, Wach M, Lewandowska M \& Rolinski JM. (2008) Increased Apoptosis of Peripheral Blood and Bone Marrow B and T Cells Correlates with Advanced Stages and Poor Risk Factors in Patients with B-CLL. Blood (ASH Annual Meeting Abstracts). 112: 4162

14. Witkowska M, Nowak W, Cebula-Obrzut B, Majchrzak A, Medra A, Robak T \& Smolewski P. (2014) Spontaneus in vitro apopotosis of de novo chronic lymphocytic leukemia cells correlates with risk of the disease progression. Cytometry B Clin Cytom, 86(6):410-7. DOI: 10.1002/cyto.b.21163

15. Huang J, Fairbrother W \& Reed JC. (2015) Therapeutic targeting of Bcl-2 family for treatment of B-cell malignancies. Expert Rev Hematol. 8(3):283-297. DOI: 10.1586/17474086.2015.1026321

16. Longo P.G., Laurenti L., Gobessi S., Sica S., Leone G. \& Efremov DG. (2008) The Akt/Mcl-1 pathway plays a prominent role in mediating antiapoptotic signals downstream of the B-cell receptor in chronic lymphocytic leukemia B cells. Blood. 111:846-855. DOI: 10.1182/blood-2007-05-089037
17. Balakrishnan K, Burger JA, Fu M, Doifode T, Wierda WG \& Gandhi V. (2014) Regulation of Mcl-1 expression in context to bone marrow stromal microenvironment in chronic lymphocytic leukemia. Neoplasia 2014;16:1036-46. DOI: 10.1016/j.neo.2014.10.002.

18. Kay NE, Bone ND, Tschumper RC, Howell KH, Geyer SM, Dewald GW et al. (2002) B-CLL cells are capable of synthesis and secretion of both pro- and anti-angiogenic molecules. Leukemia 16: 911-919. DOI:10.1038/ sj.leu. 2402467

19. Chen, H., Treweeke, A.T., West, D.C., Till, K.J., Cawley, J.C., Zuzel, M. et al (2000) In vitro and in vivo production of vascular endothelial growth factor by chronic lymphocytic leukaemia cells. Blood. 96:3181-3187

20. Gehrke I, Gandhirajan RK, Poll-Wolbeck SJ, Hallek M \& Kreuzer KA. (2011) Bone marrow stromal cellderived vascular endothelial growth factor (VEGF) rather than chronic lymphocytic leukemia (CLL) cellderived VEGF is essential for the apoptotic resistance of cultured CLL cells. Mol Med. 17(7-8):619-627.DOI: 10.2119/molmed.2010.00210

21. Lee YK, Shanafelt TD, Bone ND, Strege AK, Jelinek DF \& Kay NE. (2005) VEGF receptors on chronic lymphocytic leukemia (CLL) B cells interact with STAT 1 and 3: implication for apoptosis resistance. Leukemia. 19, 513-523. DOI: DOI: 10.1038/sj.leu.2403667

22. Lee YK, Bone ND, Strege AK, Jelinek DF \& Kay NE. (2004) VEGF receptor phosphorylation status and apoptosis is modulated by a green tea component, epigallocatechin-3-gallate (EGCG) in B-cell chronic lymphocytic leukemia. Blood 104: 788-794. DOI:10.1182/ blood-2003-08-2763

23. Maffei, R., Fiorcari, S., Vaisitti, T., Martinelli, S., Benatti, S., Debbia, G., Rossi, D., Zucchini, P., Potenza, L., Luppi, M., Gaidano, G., Deaglio, S. \& Marasca, R. (2017) Macitentan, a double antagonist of endothelin receptors, efficiently impairs migration and microenvironmental survival signals in chronic lymphocytic leukemia. Oncotarget, 27, 90013-90027. DOI: 10.18632/ oncotarget.21341

24. Veronese L, Tournilhac O, Verrelle P, Davi F, Dighiero G, Chautard E et al. (2009) Strong correlation between VEGF and MCL-1 mRNA expression levels in B-cell chronic lymphocytic leukemia. Leukemia Research. 33(12):1623-6. DOI: 10.1016/j.leukres.2009.05.003.

25. Aguayo A, Kantarjian H, Manshouri T, Gidel C, Estey E, Thomas D, Koller C, Estrov Z, O’Brien S, Keating M, Freireich E \& Albitar M.(2000) Angiogenesis in acute and chronic leukemias and myelodysplastic syndromes. Blood. 96:2240-2245.

26. Karsan A, Yee E, Poirier GG, Zhou P, Craig R \& Harlant JM. (1997) Fibroblast Growth Factor-2 Inhibits Endothelial Cell Apoptosis by Bcl-2-Dependent and Independent Mechanisms. American Journal of Pathology. 151(6):1775-84. 
27. Akl MR, Nagpal P, Ayoub NM, Tai B, Prabhu SA, Capac $\mathrm{CM}$ et al. (2016) Molecular and clinical significance of fibroblast growth factor 2 (FGF2 /bFGF) in malignancies of solid and hematological cancers for personalized therapies. Oncotarget 7(28):44735-62. DOI: 10.18632/ oncotarget.8203

28. Krejci P, Dvorakova D, Krahulcova E, Pachernik J, Mayer J, Hampl A \& Dvorak P. (2001) FGF-2 abnormalities in B cell chronic lymphocytic and chronic myeloid leukemias. Leukemia. 15:228-237.
29. Kini AR, Kay NE \& Peterson LC. (2000) Increased bone marrow angiogenesis in B cell chronic lymphocytic leukemia. Leukemia. 14:1414-1418. DOI: 10.1038/ sj.leu. 2401825

30. König A, Menzel T, Lynen S, Wrazel L, Rosén A, AlKatib A, Raveche E \& Gabrilove JL. (1997) Basic fibroblast growth factor (bFGF) upregulates the expression of bcl-2 in B cell chronic lymphocytic leukemia cell lines resulting in delaying apoptosis. Leukemia. 11(2):258-26 